\title{
ICT Industry Business Development Strategy in Indonesia (Case Study: PT. XYZ)
}

\author{
Adityo Suryo Dwiatmono ${ }^{1}$, Arief Daryanto ${ }^{2}$, Raden Dikky Indrawan ${ }^{2}$ \\ ${ }^{1,2}$ Business School, IPB University, Indonesia. \\ Corresponding Author: Adityo Suryo Dwiatmono
}

DOI: https://doi.org/10.52403/ijrr.20220256

\begin{abstract}
The condition of PT XYZ company is currently in a continuous stage of growing and developing in the ICT business industry. Seeing the huge market opportunities and the emergence of technology trends based on software and applications, PT XYZ needs breakthroughs in order to continue to compete amid increasingly competitive ICT business competition. Based on these problems, the purpose of the research is divided into three, namely: (1) Analyzing internal and external factors that affect the business development of PT XYZ; (2) Formulate alternative strategies that can be carried out for business development based on the influence of each internal and external factor on PT XYZ; (3) Formulate a strategy that is a priority in achieving business development targets at PT XYZ. This study uses SWOT and AHP methods. The results showed that SWOT analysis produced eleven strategies that were then processed using the AHP technique to obtain five priority strategies. The five priority strategies lead to market penetration strategies in business development, namely taking on IT / internet infrastructure projects in Indonesia, maintaining good relations with vendors / suppliers, developing products / services, improving standard service quality assurance, and conducting IPOs for capital strengthening
\end{abstract}

Keywords: AHP, ICT, IPO, IT, Strategi

Pengembangan Bisnis, SWOT

\section{INTRODUCTION}

PT XYZ is one of the key players in the Information Communication Technology (ICT) Industry in Indonesia. It has been established since 1994 as a distributor of Personal Computer (PC) which then transformed over 25 years into a service provider company System Integrator ICT. PT XYZ is expanding its services to ICT infrastructure and business end to end. PT XYZ is strategically located in Jakarta, the main city for finance and business in Indonesia and operates a branch office in Surabaya to include customers in eastern Indonesia. PT XYZ's vision is to become the leading ICT Company in Indonesia. This good vision is supported by a good quality policy, PT XYZ is committed to implementing an effective and efficient quality management system.

PT XYZ provides several service innovations to seize opportunities in the ICT industry, namely providing solutions from data center and cloud infrastructure, big data \&analytic, and enterprise collaboration. In addition, PT XYZ is open for consultation, implementation, and maintenance on its products. PT XYZ has consumers or customers from several sectors such as institutions, manufacturing, telecommunications, and oil and gas mining. In addition, to support its performance and services PT $\mathrm{XYZ}$ has more than 500 employees and the majority have been certified professionals.

In the process of its development, PT. XYZ received many awards, one of which, became the first company in Indonesia to win the "Cisco APJC Award" as ASEAN Partner of the Year in 2020. The award was virtually presented by Cisco Partner Summit Digital 2020, which was presented by Miyuki Suzuki (President, 
Cisco APJC and Vicki Batka (Vice President, Partner Organization, Cisco APJC) to Joko Gunawan Vice President Director, PT. XYZ. In addition to the ASEAN Partner of the Year award, in 2020 PT. XYZ was also awarded as "Indonesia IT Services Competitive Strategy Innovation and Leadership Award 2020" by Frost \&Sullivan. Frost \&Sullivan presents this award to 17 companies that have been judged innovative breakthroughs and their excellence is visible. PT XYZ also adheres to ISO standards namely Quality Management (ISO 9001), IT Service Management (ISO 20000), and Information Security Management (ISO 27001) to better serve its customers.
The award obtained by PT XYZ, does not close to continue to grow and develop. PT XYZ sees opportunities for new market segmentation that is fairly broad by looking at the development of the ICT industry and the changing times that continue to develop towards increasingly sophisticated technology. One example of the use of AI technology, big data and machine learning, namely opening a bank account does not have to come to the bank, can be remotely using laptops and mobile phones belonging to prospective customers. The technology has been successfully implemented by PT XYZ to one of its customers who is Bank BUKU IV.

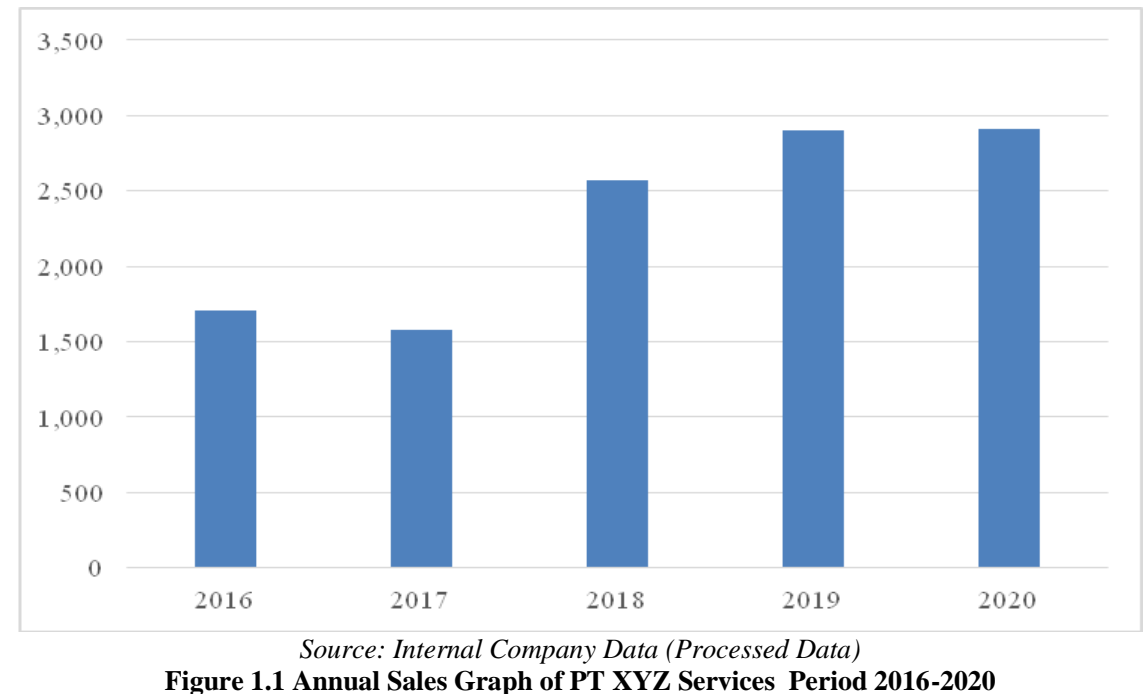

Based on Figure 1.1, it can be seen that annual sales for the period 2016-2020. PT XYZ has sales likely to increase from 2016-2020. Based on the data obtained, PT $\mathrm{XYZ}$ has the highest sales in 2020, which is 2,910 billion rupiah. Although in Indonesia's economic condition that is experiencing a recession due to the COVID19 pandemic, PT XYZ was able to increase sales from 2019 to 2020. Seeing the condition of the development and growth of PT XYZ's increasing sales and the opportunities for ICT technology needs, PT $\mathrm{XYZ}$ is expected to be able to take on the potential of the existing market in Indonesia.
Seeing the huge market potential and the emergence of technology trends based on software or applications, PT XYZ requires greater resources both financially, Human Resources (HR), technology owned and the ability to see market opportunities. So with the above problems PT XYZ needs a business development strategy in the ICT industry. Therefore, researchers are interested in lifting this research with the title ICT Industry Business Development Strategy in Indonesia (Case study: PT $\mathrm{XYZ).}$

\section{METHODS}


The research was conducted at PT. XYZ in June-August 2021. These research activities include proposals, data collection, data processing, data analysis, as well as the preparation of research theses. This study uses two types of data, namely primary data and secondary data, both in the form of qualitative data and quantitative data. Primary data was collected specifically through in-depth interviews using questionnaires to respondents who were samples in the study. These respondents are selected expert sources based on consideration of expertise, practical experience, and stakeholders. The secondary data used in this research consists of various studies of previous research literature, books, theses, and journals.

The sample collection method used in the study is with semi-structured interviews, i.e. the interviewer has prepared the topic and a list of interview guide questions before the interview begins. However, it is not closed the possibility if there are additional questions to support the answers from participants. Sampling is done using nonprobability sampling technique with purposive sampling method to determine the source who wants to be interviewed.

Table 3.1 Research Respondents

Table 3.1 Research Respondents
\begin{tabular}{|l|l|l|}
\hline Respondents & Source & Sum \\
\hline Director & Internal & $\mathbf{3}$ \\
\hline General Manager & Internal & 5 \\
\hline Manager & Internal & 5 \\
\hline Supplier & External & 2 \\
\hline Customer & External & 2 \\
\hline
\end{tabular}

The respondents in the study used purposive sampling techniques. This technique considers the selected respondents to have knowledge, expertise and experience in the field studied (Sugiyono 2013). Respondents are the parties who will answer various questions for the benefit of research. Respondents used in this study are expert respondents who are competent to give an assessment of business strategies in PT. XYZ because it knows the conditions that occur in the company. Expert respondents also provide internal and external analysis on PT. XYZ. In Table 3. 1. You can see the respondents and the resources used in this study.

The data processing and analysis techniques in this study used porter's fivestrength model, SWOT analysis, and AHP (Software Expert Choice 2000). Data obtained from research will be analyzed in several ways, namely: Internal Factors Evaluation (IFE) is intended to measure the extent of a company's strengths and weaknesses. Intuitive assessment is necessary in developing the IFE matrix, so the display of a scientific approach should not be interpreted as that this is an entirely great technique. A thorough understanding of the factors involved is more important than the actual figures (David 2016). In the internal factor evaluation matrix, the strength and weakness factors are each given weights with the numbers 0.0 (not important) to 1.0 (very important). Weights indicate the relative importance of such factors to achieve success in the industry. The weight given to existing internal factors in total must amount to 1.0. Each factor is then scored with a rating of 1 to 4 to indicate the main and small strengths and weaknesses. Rank 1 means major weakness, rank 2 means small weakness, rank 3 means small strength and rank 4 means main strength. Strength is ranked 3rd or 4th, while weakness is ranked 1 st or 2 nd.

Regardless of how many factors are incorporated into the IFE matrix, the total weighting value ranges from the lowest 1.0 to the high of 4.0, with an average value of 2.5. This total weighting below 2.5 reflects that the organization is internally weak, while a value above 2.5 indicates a strong internal position. The number of factors has no impact on the total weighting value range because the total weight amount is 1.0.

External Factors Evaluation (EFE) is used to measure the extent of a company's opportunities and threats. The EFE matrix or industrial analysis enables start-up makers to infer and evaluate economic, social, cultural, demographic, environmental, political, governmental, 
legal, technological and competitive information (David 2016). The odds and threat factors respectively in the external factor evaluation matrix are weighted by the numbers 0.0 (not important) to 1.0 (very important). Weights indicate the relative importance of such factors to achieve success in the industry. The weight given to external factors in total should amount to 1.0. Each factor is then ranked 1 to 4 to indicate how effectively the company responds to those factors. A value of 4 means an excellent response, 3 means an above-average response, a value of 2 means an average response and a value of 1 means less response.

Regardless of the number of major opportunities and threats entered into the EFE matrix, the total highest possible weighting score for the organization is 4.0 and the lowest weighting value is 1.0 . The average total weighting value is 2.5 . A total weighting value of 4.0 indicates that the organization is exceptional or great at responding to the opportunities and threats that exist in the industry. In other words, a company's strategy effectively takes advantage of existing opportunities and minimizes the potential adverse impact of external threats. A total value of 1.0 indicates the company's strategies are not taking advantage of opportunities or avoiding external threats.

SWOT analysis is used to formulate alternative strategies. SWOT analysis is based on the results of internal factors analysis and external factors analysis formulations that produce a combination of internal and external factors. The SWOT matrix is a tool used to devise strategic alternatives of a company. Opportunities and threats are clearly described through the SWOT matrix and adapted to strengths and weaknesses. David (2016) states that the matching stage is a grouping of alternative strategies generated in SWOT analysis with grand strategy seen from the results of IE matrix analysis, the goal is that the company can determine the right strategy to do. Swot analysis can be described as follows:
Strengths (S) are a resource, skill or other advantage over competitors and the needs of the market. Strength is a distinct competence so that the company has a comparative advantage in the market. Strength relates to financial resources, image, market leadership, buyer and supplier relationships and other factors.

Weaknesses (W) are limitations or deficiencies in resources, skills and abilities that seriously hinder the effective performance of a company.

Opportunity (O) is a major favorable situation in the corporate environment. Identification of previously missed market segments, changes in competition circumstances, government regulations, technology and good relationships with buyers and suppliers is a corporate business opportunity.

Threats (T) are unfortunate situations for the company, namely the main obstacles to the current or desired position of the company, including the entry of new competitors, slow market growth, increased bargaining power of buyers and suppliers, technological changes and new regulations that pose a threat to the success of the company.

Fahmi (2013) states that the tool used to structure the factors of a company's strategy is the SWOT matrix. The SWOT matrix produces several strategy options (Solihin 2012). The SWOT matrix will produce four strategic possibilities cells (Summary 2016). The SWOT matrix includes SO, WO, ST, and WT strategies. SWOT analysis can be done with information obtained from the results of external, internal analysis and review of managerial values. The information obtained is used to thoroughly analyze the situation faced by the company and formulate steps that can be taken to anticipate the possibilities that can occur. Four types of SWOT matrix strategies are:

Strengths-Opportunities (S-O) Strategies, It is an aggressive strategy, because it optimizes the power you have to take advantage of existing opportunities. 
Weaknesses-Opportunities (W-O) Strategy, It is a stability strategy or rational strategy, because it minimizes weaknesses in utilizing existing opportunities.

Strengths-Threats (S-T) Strategies, It is a diversification strategy that harnesses power in the face of threats.

Weaknesses-Threats (W-T) Strategy, This strategy is based on defensive activities to minimize existing weaknesses in the face of incoming threats.

Decision making in research using the AHP method will be done using the Software Expert Choice 2000 application. The hierarchy is structured as shown in Figure 3.1 which is the integration between components in SWOT using the AHP structure. The end result is the importance of strategic priorities that will be recommended to experts. The description of sub-factors is obtained from the results of alternative strategies a combination of strengths, weaknesses, opportunities, and threats using SWOT matrix tools. Kangas et al. 2001 state that this AHP is used to give weight to each level and provide an assessment to determine the exact strategy of the alternative strategies generated in the SWOT matrix.

Respondents will fill out a questionnaire for the level of hierarchy after the preparation of the hierarchy. Weighting is first done at the level of factors and subfactors by expert respondents. Weighting at the factor level is a paired comparison between strengths, weaknesses, opportunities, and threats. The weighting technique is carried out using a paired comparison method with the condition that the validity of the inconsistency valuation ratio is more less or equal to $10 \%$.

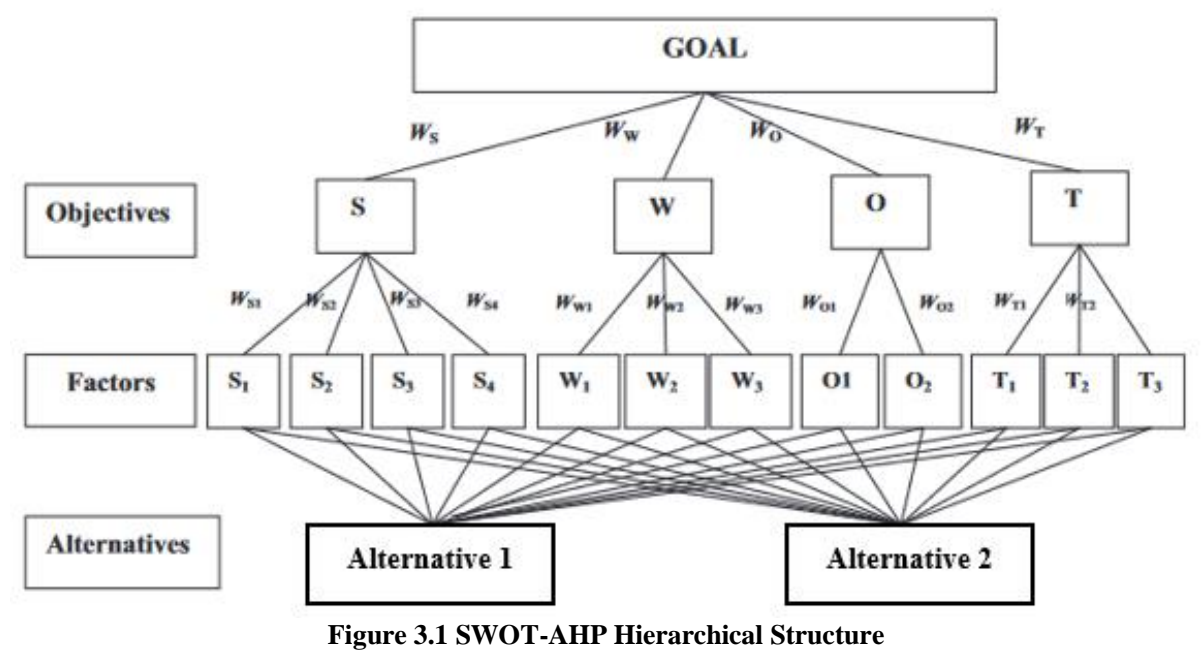

\section{RESULT}

PT XYZ was established in 1994 and is a System Integrator and Solution Provider company in the field of Information and Communication Technology (ICT). PT XYZ provides ICT Infrastructure solutions, System Integration services, run by management with more than 25 years of experience.

PT. XYZ has cooperated with many technology vendors, one of them with Cisco Systems, to support the System Integration project in Indonesia. PT XYZ's commitment is to provide the best services and solutions to get a high level of satisfaction from customers. PT XYZ has 18 CCIE (Cisco Certified Internetwork Expert) certified people, which is the highest certification in Cisco to meet technical support needs for customers. PT XYZ also has various ISO certifications namely ISO 9001:2015 (Quality Management System), ISO 20000: 2011 (IT Service Management System), and ISO 27001:2013 (Information Security Management). This certainly shows the capability and competence of PT XYZ in 
handling various large carrier class projects in Indonesia.

PT. XYZ has grown to become one of the top system solution providers and integrators, providing the best service in consulting and system integration to provide one-stop solutions for all network and peripheral elements, business applications, and structured cable systems. The following are some of PT XYZ's achievements in various technologies:

\section{Cisco Systems:}

1. ASEAN Partner of the Year 2020 (2020)

2. FY20 Indonesia Partner of the Year (2020)

3. FY20 Enterprise Partner of the Year (2020)

4. FY20 Multi Architecture Partner of the Year (2020)

5. FY20 Recurring Offer Partner of the Year (2020)

6. FY20 Services Partner of the Year (2020)

7. FY20 SP System Engineer of the Year (2020)

8. FY20 Enterprise System Engineer of the Year (2020)

9. FY20 Enterprise Field Engineer of the Year (2020)

10. FY19 Partner of the Year (2020)

11. FY19 Enterprise System Engineer of the Year (2020)

12. FY19 Enterprise Field Engineer of the Year (2020)

13. FY19 Multi Architecture Partner of the Year (2020)

14. Digital Innovation Award Cisco APJC (2018)

15. Top Three Partner of the Year (FY 2018)

16. The Most Innovative Partner of the Year (FY 2018)

17. Partner of the Year (FY 2011-2017)

18. Cisco Capital Partner of the Year (2015)

\section{Outstanding Performance ASEAN Security Partner (FY2015)}

20. Best Collaboration Partner (FY 2014)
21. The Most Improved Services Partner (2012)

22. The Best System Integrator Partner (2011-2012)

23. The Best Services Sales Partner (2011)

24. Best Purchasing (2008)

25. Best System Engineer (2008)

26. Best Partner 2008 for Advance Technology.

27. Best Purchasing (2007)

28. Best System Integrator Partner (2007)

29. Best System Engineer (2006)

30. Best System Integrator Partner (2006)

\section{Microsoft:}

1. Indonesia Partner of the Year Award (2017)

2. Best Coop Found Utilization to Transform BUSSINES

3. Best Partner of the year (2012)

4. Best Partner of the year (2011)

5. Microsoft Networking Infrastructure Solutions Best Partner

6. Microsoft Unified Communication Best Partner

7. Microsoft APOC Channel Ops Readiness In Recognition of Professional Certification on Volume Licensing (2008)

8. Highest VL Revenue Contributor for Unified Communication

9. Highest VL Revenue Contributor for Windows Server Systems

10. Best Partner for Annuity Sales

11. Best LAR for Revenue Contribution

12. Best Partner of the year (2007)

13. Best MSPP Competency

14. Best LAR for Revenue Growth

15. Best LAR for Revenue Contribution

16. Best Partner of the year (2006)

17. Best Partner of the year 2005

HP:

1. The Most Outstanding Storage Essential Partner (2010)

2. The Top Performing Storage Partner Sales (2011)

3. The Best Achievement Sales (2012)

4. Enterprise Group HP Storage Corporate Reseller - Best Partner Award (2014) 
5. Fastest Growing Hybrid IT Corporate Reseller Enterprise \& PS (FY 2017)

6. Platinum Partner 2019: Recognition of Outstanding Performance

PT XYZ's current focus is on computer networking and System Integrator. Since its establishment, PT XYZ has focused on always improving and developing the capabilities of its employees.
Until now PT XYZ has developed the capabilities of experts and obtained certification from several major IT vendors in the world today. The close relationship between PT XYZ and Cisco, and other vendors, enables PT XYZ to expand support and service for customer needs and satisfaction. Here are some of the world's major ICT vendor partners:

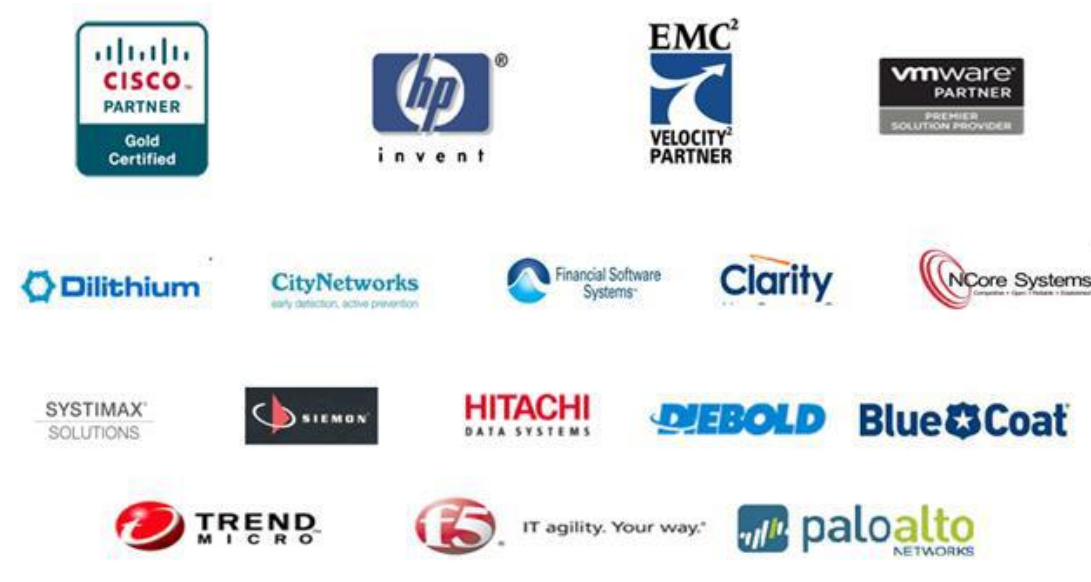

Figure 4.1 Main ICT Vendor/Supplier of PT XYZ

Porter's Five Forces Model analysis is used to analyze a company's external environment from industry competitive conditions that have an influence on business continuity. Hitt, Ireland, Hoskisson (2001) defines the industrial environment as the threat factors of new business people, suppliers, buyers, substitute products, and the intensity of competition among competitors that directly influences the company as well as its competitive response.

Porter (2008) developed the concept of a competitiveness strategy that analyzes business competition based on five main aspects, namely barriers to entry, supplier strength, buyer strength, availability of substitute goods, and competition between companies. This analytical tool is known as Porter's five forces and is widely used by both researchers and businesses for the analysis of industry competition factors.

Nurseto (2012) is a challenge for companies to place a position in an industry where the company can profitably and influence environmental factors so that the company is able to defend itself from the influence of industry competition. The greater the company's capacity to better influence the industrial environment, the more likely it is to make a profit over its competitors.

Information and communication technology competition faces monopolistic market conditions, so identification of the influence of industrial environmental factors needs to be done. Identification of environmental factors is done by descriptive analysis to find out the picture of company competition on five factors of industry competition in the information and communication technology industry. The competitive picture in the industrial environment is described into threats and opportunities, so that companies can overcome the influence of the industry. Bright (2004) Analysis porter's five force can help to know the benefits of current and future competitive positions that will be faced later, so that the company can devise 
strategies to minimize threats and take advantage of existing opportunities. Identification of factors affecting the information technology industry and based on analysis of Porter's five forces industrial environment.

\begin{tabular}{|c|c|c|c|}
\hline \multicolumn{4}{|c|}{\begin{tabular}{l|l} 
Issue Identification & Impact on PT XYZ
\end{tabular}} \\
\hline \multirow[t]{3}{*}{$\begin{array}{l}\text { Competition } \\
\text { between similar } \\
\text { businesses }\end{array}$} & $\begin{array}{l}\text { There are only } 6 \text { Cisco Gold Partners } \\
\text { out of } 128 \text { similar companies in } \\
\text { Indonesia. }\end{array}$ & $\begin{array}{l}\text { Low } \\
\text { competition }\end{array}$ & $\begin{array}{l}\text { PT XYZ is included in Cisco's } 6 \text { Gold Partners so that } \\
\text { it is able to compete in selling Cisco products in } \\
\text { Indonesia. }\end{array}$ \\
\hline & $\begin{array}{l}\text { The selling price of PT XYZ goods } \\
\text { competes compared to } 128 \text { similar } \\
\text { companies }\end{array}$ & $\begin{array}{l}\text { Low } \\
\text { competition }\end{array}$ & $\begin{array}{l}\text { Pt XYZ's goods price is competitive because it has } \\
\text { been trusted to be Cisco's Gold Partner }\end{array}$ \\
\hline & $\begin{array}{l}\text { Compared to cisco's other Gold } \\
\text { Partner companies, PT XYZ is also } \\
\text { difficult to provide stock of goods. }\end{array}$ & $\begin{array}{l}\text { High } \\
\text { competition }\end{array}$ & $\begin{array}{l}\text { The potential of PT XYZ is not able to sell Cisco } \\
\text { products to customers quickly, so customers will } \\
\text { choose other similar companies. }\end{array}$ \\
\hline \multirow[t]{3}{*}{ Supplier } & $\begin{array}{l}\text { There are } 35 \text { IT product vendors and } \\
50 \text { suppliers of IT support companies. }\end{array}$ & $\begin{array}{l}\text { Low supplier } \\
\text { strength }\end{array}$ & $\begin{array}{l}\text { PT XYZ works closely with several vendors/suppliers. } \\
\text { PT XYZ has the right to determine the product of the } \\
\text { vendor / supplier in accordance with the needs of PT } \\
\text { XYZ customers. }\end{array}$ \\
\hline & $\begin{array}{l}\text { PT XYZ is the top } 3 \text { ICT system } \\
\text { integrator companies in Indonesia }\end{array}$ & $\begin{array}{l}\text { Low supplier } \\
\text { strength }\end{array}$ & $\begin{array}{l}\text { Vendor / supplier expects PT XYZ to cooperate by } \\
\text { selling products from vendors / suppliers }\end{array}$ \\
\hline & $\begin{array}{l}\text { Vendors/suppliers also cooperate } \\
\text { with } 128 \text { other similar companies. }\end{array}$ & $\begin{array}{l}\text { High supplier } \\
\text { power }\end{array}$ & $\begin{array}{l}\text { PT XYZ must be able to maintain good relations with } \\
\text { vendors / suppliers so that PT XYZ becomes a priority } \\
\text { customer of vendors / suppliers. }\end{array}$ \\
\hline \multirow[t]{4}{*}{ Customer (customer) } & $\begin{array}{l}\text { There is a } 5 \% \text { growth in the number } \\
\text { of new customers per year }\end{array}$ & $\begin{array}{l}\text { Customer } \\
\text { strength } \\
\text { (customer) } \\
\text { low }\end{array}$ & Customer price bargaining power to $\mathrm{PT} \mathrm{XYZ}$ is low \\
\hline & $\begin{array}{l}\text { The results of customer satisfaction } \\
\text { survey of products and services } \\
\text { provided by PT XYZ worth }>90\end{array}$ & $\begin{array}{l}\text { Customer } \\
\text { strength } \\
\text { (customer) } \\
\text { low }\end{array}$ & $\begin{array}{l}\text { Good judgment by the customer (customer) makes the } \\
\text { opportunity for repeat order (repeat order) }\end{array}$ \\
\hline & $\begin{array}{l}\text { ICT development index in Indonesia } \\
\text { is growing } 5.59 \% \text { per year }\end{array}$ & $\begin{array}{l}\text { Customer } \\
\text { strength } \\
\text { (customer) } \\
\text { low }\end{array}$ & $\begin{array}{l}\text { Every year the growth trend of the need for ICT } \\
\text { services is increasing. }\end{array}$ \\
\hline & $\begin{array}{l}\text { Customers can choose Cisco products } \\
\text { at competitive prices from only } 6 \\
\text { Cisco Gold Partner companies. }\end{array}$ & $\begin{array}{l}\text { Customer } \\
\text { strength } \\
\text { (customer) } \\
\text { low }\end{array}$ & $\begin{array}{l}\text { Customer choice (customer) only a few can choose } \\
\text { Cisco products }\end{array}$ \\
\hline $\begin{array}{l}\text { Replacement } \\
\text { products } \\
\text { (substitutes) }\end{array}$ & $\begin{array}{l}\text { There is a potential for technological } \\
\text { transition. }\end{array}$ & $\begin{array}{l}\text { Potential } \\
\text { threats are }\end{array}$ & $\begin{array}{l}\text { PT XYZ must be able to adapt and master the } \\
\text { technology to come. }\end{array}$ \\
\hline Newcomers & $\begin{array}{l}\text { It's hard to set up a business of some } \\
\text { kind. }\end{array}$ & $\begin{array}{l}\text { Potential threat } \\
\text { is low }\end{array}$ & $\begin{array}{l}\text { To build a similar business requires a very large capital } \\
\text { and takes a long time to be trusted by vendors / } \\
\text { suppliers and customers (customers). }\end{array}$ \\
\hline
\end{tabular}

The results of descriptive analysis presented in Table 4.1 show that all environmental factors of the information and communication technology industry provide more opportunities than threats. This illustrates that the competition faced by PT XYZ is very competitive and has a very large opportunity.

At the evaluation stage of internal factors, interviews were conducted to identify internal factors that were influential in the business development of PT XYZ. According to Rangkuti (2015), the preparation of the results of identification of internal factors that affect the company is important to formulate an IFE (Internal Factor Evaluation) table containing these internal strategic factors within the framework of strength and weakness. IFE analysis is the result of internal factors consisting of strengths and weaknesses that PT XYZ has.

The results of weighting and rating on internal factors are based on sources / informants through interviews with General Manager Solution Architect and Director of Technology and Solution related to PT XYZ. internal factors (strength) IFE can be seen that there are various ratings on the strength factor of PT XYZ. Factors that 
have a rating with a value of 4 (outstanding) is the largest factor and is the most influential factor on the strength of PT $\mathrm{XYZ}$, namely as follows:

1. Trusted by 10 vendors / suppliers as (Partner of the Year) has a score of 1.04

2. PT XYZ has 20 CCIE certified employees from 50 CCIE certified Network Engineers in Indonesia has a score of 0.72

3. PT XYZ has a strong relationship with customers (customers) of the financial sector compared to other competitors has a score of 0.64 .

While the power factor of PT XYZ that has the least influence is as follows:

1. Having quality standards ISO 9001:2015 (Quality Management), ISO/IEC 200001:2011 (IT Service Management) and ISO 27001:2013 (Information Security Management) have a score of 0.48

2. Having a work culture from everywhere has a score of 0.30

INTERNAL factors (weaknesses) ife can be seen that there are various ratings on the weakness factor of PT XYZ. Factors that have a rating with a value of 1 are the most influential weakness factors on PT XYZ, namely:

1. Lack of funds / business capital with a score of 0.01

2. No employee has a software-based certification with a score of 0.03 .

While the weakness factors of PT $\mathrm{XYZ}$ that have the least influence are as follows:

1. There are no adequate laboratory facilities available for the development of employee expertise has a score of 0.08

2. Not yet have cooperation with health insurance companies for employees has a score of 0.09

3. Social Media (Instagram) PT XYZ only has followers below 2000 followers compared to competitors who have followers reaching 4500 followers have a score of 0.11

Maulana (2016) explained in his research that the external environment of a business is factors that have limits beyond the control of the business but the existence of these factors also influences the choice of direction and action of the business venture. The external environment is divided into three interrelated sub-categories, namely the remote environment, the industrial environment, and the operational environment. Distant environments are also called macro environments or general environments because they contain components whose influence is broad and included in the entire business process. The weighting and rating of external factors (EFE) of PT XYZ is based on sources / informants through interviews regarding PT $X Y Z$. Average of external factors (odds) of PT XYZ

Opportunity factor PT XYZ. Factors that have a rating with a value of 4 (outstanding) is the most likely factor to affect PT XYZ. The factors that have the greatest value are indicated by a score of 1 , namely:

1. IT /internet infrastructure in Indonesia has not been evenly distributed with a score of 1

2. Trusted by customers with a large capitalization with a score of 0.42

Threat Factor to PT XYZ. The factor that has the rating with the smallest value has a large influence on PT XYZ is the product dependence of vendors / suppliers who have a score of 0.08 . The least influential threat factor for PT XYZ is that the PPKM/regional quarantine regulations cause potential delays in completion of projects that have a score of 0.24 .

PT XYZ has potential that can be beneficial or detrimental to PT XYZ. The effect caused can have positive or negative consequences depending on the strategic policy steps taken by PT XYZ. Positive influence can give PT XYZ the opportunity to further develop while negative influences will hinder the development of PT XYZ. The PEST approach is used to see how much influence external environmental conditions have on the development of PT XYZ. 


\section{a. Politics}

The

construction

of

telecommunication connectivity became a homework for the government. Not without reason, the existence of information and communication technology infrastructure will be a catalyst for Indonesia's economic and social growth. ICT infrastructure is the capital of economic, social, and other material growth in Indonesia. Therefore, it is necessary to focus on developing ICT infrastructure until the next 20 years. Since 2005, the Government has paid special attention to the development of telecommunication connectivity. At that time, the Palapa Ring Project was initiated to unite Indonesia through telecommunication access. The effort was accelerated through Presidential Regulation No. 96 of 2015 on broadband plans for 2014-2019.

In the global context, to go to Government 4.0, Indonesia is indeed better than Paraguay, then Egypt, Libya, Myanmar, Sudan. But it remains below Thailand and below neighboring countries in the ASEAN region. The Minister of Communication and Information expects that in the future there will be an increase in service capacity and infrastructure improvements. Because there is an increase in use for vital sectors, namely the government sector, the health and education sector and public services.

Therefore, it is expected that there is a role carried out by the private sector to help the government realize Government 4.0 through accelerating ICT infrastructure development. The enthusiasm of digital service providers such as PT XYZ will automatically increase because they realize that the need for domestic digital services is still low, so they have a very large opportunity in participating in ict infrastructure development efforts in Indonesia.

\section{b. Economy}

Indonesia's economy, especially the GDP of the information and communication sector, consistently experienced positive year-on-year (y-o-y) growth in 2021, which was 9.82 percent in the first quarter; 10.85 percent in the first quarter; 10.72 percent in the third quarter; and 10.91 percent in the fourth quarter. It is seen that there was an increase from quarter 1 to quarter 2 and quarter 3 to 4 . The increase in GDP from the information and technology sector can be said that the information and technology sector becomes a business opportunity and income for the Indonesian state. In addition, the condition of rupiah exchange rate stability against the dollar makes products imported from abroad relatively controlled. The condition of exchange rate stability between rupiah and dollar becomes an opportunity for business players in the information and communication sector, one of which is PT XYZ. In addition, the Government targets for either individuals or communities to reduce dependence on pirated or illegal products in the sense of the information and communication sector.

\section{c. Social}

Emergency PPKM greatly affects all community activities, such as non-essential office activities must do WFH or Work From Home, as well as eating and drinking activities in food stalls, restaurants, cafes, street vendors, hawkers, both stand-alone and in shopping centers / malls are only allowed to receive delivery services / takeaway and do not accept on-site dining (dine-in). Therefore, the essential and critical economy is needed to meet the basic needs of the community, especially to meet the needs of eating and drinking. This makes the shift of people's habits towards digitalization.

There are several things that are of concern in the competition in the information and communication industry. The existence of PPKM policy, office activities become WFH and community habits towards digitalization create opportunities for PT XYZ.

\section{d. Technology}


Indonesia has a new beginning of the information and communication sector, especially information technology, namely the entry of 5G mobile networks. The acceleration of digital transformation itself was stated by the Minister of Communication and Informatics (Kominfo), the acceleration itself will affect the integration of human networks with machines and also communication. In addition, the development of big data is defined as an information asset characterized by $3 \mathrm{v}$ characteristics, namely: high volume, velocity and variety, which require certain methods and technologies to process it into value in decision making. Information assets are important, because data is considered to have as high value to the organization as other assets (machinery, materials, people, capital, and methods) and can be validated (valued in units of money). Big data itself in Indonesia becomes an opportunity, which lately is quite rife hackathon related to Big Data. Whether it's organized by the private sector or the government. This hackathon itself is a competition that competes IT solutions from participants by utilizing data provided by the organizers. With this hackathon data owners can get a variety of innovative ideas from participants. It is not uncommon for the solution of a hackathon winner to be implemented in real terms. Here are some of the hackathons that have recently been held: Kemenkeu Hackathon 2021, Big Data Hackathon BPS 2021, in a RISK Hackathon Fest 2021, and others. In addition, from the government side, the Open Data policy is the only one. With this policy, the government encourages government agencies (both central and regional) to publish their data. Openness of data, can increase public participation in solving problems around.

Therefore, PT XYZ as a company engaged in the communication and information sector can provide services both in the form of data collection, compilation, data cleaning and visualization, and PT XYZ must immediately train employees and labor absorption in the implementation of big data. In addition, PT XYZ can provide a division to be able to read insights as well as information as well as good data visualization and storytelling capabilities displayed by big data.

The performance of a company can be determined by a combination of internal and external factors. Both factors should be considered in a SWOT analysis. SWOT stands for internal strengths and weakness environments as well as the external environment of opportunities and threats faced in the business world. SWOT analysis can compare external factors of opportunity (opportunities) and threats (threats) with internal factors strengths (strengths) and weaknesses (weaknesses).

Based on the SWOT matrix, there are various strategies that can be used by PT XYZ. But seeing the condition of PT XYZ which has a strong internal position and is able to take advantage of opportunities, then PT XYZ should conduct a SO (Strength Opportunities) strategy by using the power to take advantage of existing opportunities through expanding the market by increasing sales of existing products as well as sales of new products and WT (Weakness Threat) strategies to fix weaknesses that can minimize the threat by doing so for internal repairs of PT XYZ.

Strategy prioritization is done by the Analytic Hierarchy Process (AHP) method which is one of the methods commonly used in making a priority sequence of various choices that can then be used to help make a decision. AHP will be used to obtain the priority sequence of strategies from the eleven strategies generated in the previous SWOT analysis. The hierarchy used in AHP consists of three levels: influential actors, the main objectives to be carried out, and the strategies used to achieve the goals. 


\begin{tabular}{|c|c|c|}
\hline & $\begin{array}{l}\text { from 83 CCIE certified Network Engineers in } \\
\text { Indonesia. } \\
\text { 2. PT XYZ has a strong relationship with } \\
\text { customers (customers) of the financial sector } \\
\text { compared to other competitors. } \\
\text { 3. Have a work culture from anywhere } \\
\text { 4. Has quality standards ISO 9001:2015 } \\
\text { (Quality Management), ISO/IEC 20000- } \\
\text { 1:2011 (IT Service Management) and ISO } \\
27001: 2013 \text { (Information Security } \\
\text { Management) vendors/suppliers as (Partner } \\
\text { Trusted by 10 vendors } \\
\text { of the Year) }\end{array}$ & $\begin{array}{l}\text { 2. We dification. } \\
\text { We don't have a partnership with a } \\
\text { health insurance company for } \\
\text { employees. } \\
\text { 3. Social Media (Instagram) PT XYZ } \\
\text { only has followers below 2000 } \\
\text { followers compared to competitors who } \\
\text { have followers reaching } 4500 \\
\text { followers. } \\
\text { There are no adequate laboratory } \\
\text { facilities available for the development } \\
\text { of employee expertise. } \\
\text { 5. Lack of funds / business capital }\end{array}$ \\
\hline $\begin{array}{l}\text { OPPORTUNITY }(\mathbf{O}) \\
\text { 1. It/internet infrastructure in } \\
\text { Indonesia has not been evenly } \\
\text { distributed. } \\
\text { 2. The trend of digital } \\
\text { transformation implementation } \\
\text { in Indonesia. } \\
\text { 3. Customer data security needs } \\
\text { are increasing. } \\
\text { 4. More and more experts in the } \\
\text { field of ICT. } \\
\text { Trusted by customers } \\
\text { (customers) with a large } \\
\text { capitalization. }\end{array}$ & $\begin{array}{ll}\text { STRATEGY (SO) } \\
\text { 1. } \\
\text { Take the IT/Internet Infrastructure Project in } \\
\text { Indonesia (S1, S2, S3, S4, O1, O2, O4) } \\
\text { 2. } \quad \begin{array}{l}\text { Selling HKI / Intelectual property products } \\
\text { from PT XYZ (S2, S3, S4, O2, O4, O5) }\end{array} \\
\text { 3. } \begin{array}{l}\text { Perform product/service development } \\
\text { strategies (S1, S2, S3, S4, O1, O2) }\end{array}\end{array}$ & $\begin{array}{l}\text { STRATEGY (WO) } \\
\text { 1. Recruiting software-based experts (W1, } \\
\text { W4, O1, O2, O3, O4, O5) } \\
\text { 2. Providing training to improve the } \\
\begin{array}{l}\text { expertise of software-based employees } \\
\text { (W1, O1, O2, O3, O5) }\end{array} \\
\text { 3. Improving facilities and facilities for } \\
\text { employees (W2, W4, O4, O5) }\end{array}$ \\
\hline 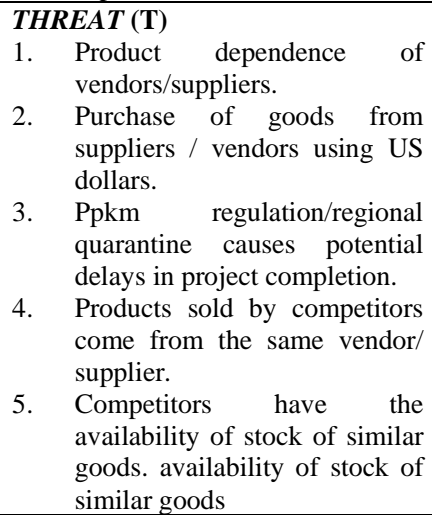 & $\begin{array}{l}\text { STRATEGI (ST) } \\
\text { 1. Maintain good relations with } \\
\text { vendors/suppliers (S1, S4, S5, T1, T4) } \\
\text { 2. Improve adaptive work culture with new } \\
\text { lifestyle habits (S3, T3) } \\
\text { 3. Improve standard service quality assurance } \\
\text { (S1, S4, S5, T4, T5) }\end{array}$ & $\begin{array}{l}\text { STRATEGY (WT) } \\
\text { 1. Ipo for capital strengthening (W1, W2, } \\
\text { W4, W5, T2, T5) } \\
\text { 2. Increase promotion and popularity } \\
\text { through social media (W3, T4) }\end{array}$ \\
\hline
\end{tabular}

Figure 4. 2 SWOT Matrix of PT XYZ

Table 4.2 AHP Strategy
\begin{tabular}{|l|l|l|l|}
\hline STRATEGY & INFORMATION & WEIGHT & RANK \\
\hline SO 1 & Taking on the IT/Internet Infrastructure Project in Indonesia & 0.43 & 1 \\
\hline ST 1 & Maintain good relationships with vendors/suppliers & 0.29 & 2 \\
\hline SO 3 & Implement product/service development strategies & 0.23 & 3 \\
\hline ST 3 & Improve the quality assurance of standardized service & 0.19 & 4 \\
\hline WT 1 & Conduct an IPO to strengthen capital & 0.19 & 5 \\
\hline
\end{tabular}

The priority strategy generated by AHP demonstrates the ability of each strategy to meet the objectives of the previous level. Every strategy has the ability to achieve the desired goal. It can be known that the sequence of strategies in the AHP indicates the priority order of the execution time of the strategy based on the implementation time frame, so the first strategy does not have to be implemented first. The priority used in AHP is also not a process for choosing a strategy, meaning that each strategy can be used simultaneously or independently depending on the ability and resources available to achieve a particular goal.

Some of the activities of the strategy application involve internal and external parts such as customers, vendors/suppliers, as well as other third parties involved in PT XYZ's business processes.

\section{Take on IT/internet infrastructure projects in Indonesia}

There are two major problems faced by Indonesian people in accessing the internet, namely the coverage of the area covered by internet signals and slow internet speeds. The geographical condition of 
Indonesia which is an archipelago country is a major factor of challenges in fulfilling the availability of internet services to the $3 \mathrm{~T}$ area (leading, outermost, lagging). The area outside the island of Java becomes the most areas that have not been reached by the internet. There are 70 million Indonesians who still have difficulty getting internet access. The government targets in 20212022 to be the year of internet infrastructure development where as many as 7,904 villages / villages that are currently not affordable internet can enjoy $4 \mathrm{G}$ networks to push the digital economy to remote areas. With the internet network infrastructure development program, PT XYZ is expected as an ICT company to be able to take on the huge market potential.

\section{Maintain good relations with vendors/suppliers}

In meeting the needs of its customers PT XYZ is very dependent on cooperation carried out with third parties, namely vendors / suppliers. Vendors here are ICT goods manufacturers and suppliers here, namely supporting facilities supply companies such as cables, shelves, and others. The role of vendors is very large in the business process of PT XYZ with its customers because PT XYZ brings the global IT vendor brand to customers so that customers trust the services offered by PT $\mathrm{XYZ}$, in addition a good relationship between PT XYZ and vendors / suppliers will determine the purchase price obtained by PT XYZ from vendors or suppliers so that the resale price to PT XYZ customers It will be more competitive than the price of its competitors.

\section{Perform product/service development.}

With the increasingly diverse customer needs also supported by the increasing cooperation between $\mathrm{PT}$ XYZ and new vendors, PT XYZ is expected to be able to develop products or services offered to its customers both old customers and prospective new customers. The development of a new product or service is very possible by collaborating between working vendors and new vendors so that the products offered are increasingly diverse.

\section{Improve the quality assurance of standardized service}

To improve customer satisfaction, PT XYZ is expected to always be able to always improve the quality assurance of services in accordance with the certification standards owned by PT XYZ, namely ISO 9001:2015 (Quality Management), ISO / IEC 20000-1: 2011 (IT Service Management) and ISO 27001: 2013 (Information Security Management). With the improvement of service in accordance with the certification owned by PT XYZ, PT $X Y Z$ will get several benefits, namely reputation or credibility, customer satisfaction, and cost efficiency in project management.

\section{Conduct an IPO for capital strengthening}

Capital or cost is an obstacle experienced by PT XYZ at this time, lack of capital causes the difficulty of PT XYZ in procurement or provision of goods stock in warehouses, large capital is also needed to develop original products created by PT XYZ (Intellectual Property Rights). Initial Public Offering (IPO) is one of the options that are pegged to be considered in an effort to strengthen capital to carry out business development in the future.

\section{CONCLUSION}

Internal and external conditions that affect the business development of PT XYZ are factors of strengths and weaknesses owned by PT XYZ, these factors include having 20 CCIE certified employees, having strong relationships with financial sector customers, having a work culture from everywhere, having iso 9001:2015 quality standards (Quality Management), ISO/IEC 20000-1:2011 (IT Service Management) and ISO 27001: 2013 (Information Security Management), trusted by 10 vendors as 
Partner of the Year, no employees who have software-based certification, do not have cooperation with insurance companies for employees, Social Media (Instagram) PT XYZ only has followers under 2000 followers, the availability of adequate laboratory facilities for the development of employee expertise, and lack of funds or business capital. As for external factors that are opportunities and threats to PT XYZ, including currently IT / internet infrastructure in Indonesia has not been evenly distributed, the trend of digital transformation implementation in Indonesia, the need for customer data security is increasing, the increasing number of experts in the field of ICT, PT XYZ is trusted by customers (customers) with a large capitalization, the existence of product dependency from vendors / suppliers, Purchase of goods from vendors / suppliers using US dollars, in the pandemic period applied PPKM regulations / quarantine areas that cause potential delays in project completion, some products sold by competitors come from the same vendor / supplier, and competitors have the availability of stock of similar goods.

SWOT analysis results in eleven strategies that are then processed using the AHP technique to get five priority strategies. The five priority strategies lead to market penetration strategies in business development, namely taking on IT / internet infrastructure projects in Indonesia, maintaining good relations with vendors / suppliers, developing products / services, improving standard service quality assurance, and conducting IPOs for capital strengthening.

Acknowledgement: None

Conflict of Interest: None

Source of Funding: None

REFERENCES
1. Allahawiah S, Al-Mobaideen $\mathrm{H}$, Nawaiseh KA. 2012. The Impact of Information Technology on Knowledge Management Processes: An Empirical Study in the Arab Potash Company. International Business Research. 6(1): 235-252.

2. Azizah M, Yustanti W. 2019. Pemilihan metode risk assessment ada UPT-TIK di perguruan tinggi menggunakan metode AHP (Analytical Hierarchy Process) (Studi kasus: UPT-TIK Wilayah Kota Surabaya). Jurnal Manajemen Informatika 10(1):10-18.

3. Ashshidiqy H, Ali H. 2019. Penyelarasan teknologi informasi dengan strategi bisnis. Jurnal Ekonomi dan Manajemen Sistem Informasi. 1(1):51-59.

4. Bogdanovic D, Ljubic S, Blagojevic S, Tomic N, Bogosavljevic D. 2018. The implementation of the hybrid SWOT-AHP model in the case of strategic decision making inthe informatics industry: A case study. International May Conference on Strategic Management:790-813.

5. Budiarto. 2019. Analisis pengembangan Business Model Canvas dalam upaya meningkatkan keunggulan bersaing PT. XYZ. Jurnal Manajemen Bisnis dan Kewirausahaan. 3(1):90-95.

6. Burhan Ahmad B. 2018. Pemanfaatan Teknologi Informasi dan Komunikasi untuk Pengembangan Ekonomi Pertanian dan Pengentasan Kemiskinan. Jurnal Komunikasi Pembangunan.

7. Burt RS. 2000. The network structure of social capital. Research in Organizational Behavior, Vol. 22. R.I Sutton and B.M. Staw, Eds. Greenwich: JAI Press.

8. Chaniago SA. 2014. Perumusan manajemen strategi pemberdayaan zakat. Jurnal Hukum Islam. 12(1):87-101.

9. David FR. 2016. Manajemen Strategik Suatu Pendekatan Keunggulan Bersaing. Puspasari, Novita, penerjemah; Dedy A, editor. Jakarta (ID): Salemba Empat. Terjemahan dari: Strategic Management. A Competitive Advantage Approach, Concepts amd Case.

10. David FR. 2010. Manajemen Strategi: Konsep. Jakarta: Salemba Empat edisi 12.

11. David FR. 2011. Strategic Management: Consepts and Cases. Edition 13th Pearson Education

12. Dwiastuti I. 2008. Analisis manajemen strategi industri alternatif (Studi Kasus 
Biofuel). Jurnal Ekonomi dan Pembangunan. 16(1):21-33.

13. Fahmi I. 2013. Manajemen Strategis: Teori dan Aplikasi. Bandung (ID): Alfabeta.

14. Friedman T. 2005. The World is Flat: A Brief History of the 21st Century. New York: Farrar, Straus and Giroux.

15. Ge X. 2010. Information-Seeking Behavior in the Digital Age: A Multidisciplinary Study of Academic Researchers. College \& Research Libraries. 435-455.

16. Granovetter M. 2005. The impact of social structure on economic outcomes. Journal of Economic Perspectives 19(1):33-50.

17. Hampton KN, Sessions LF, Her EJ, Rainie L. 2009. How the Internet and Mobile Phones Impact Americans' Social Networks. Princeton Survey Research Associates International.

18. Herfita D, Widyastuti T, Gustari I. 2017. Analisis strategi bisnis pada PT Gancia Citra Rasa. Jurnal Eksekutif. 14(2):369-383.

19. Jayalaksmi B, Pramod VR. 2013. Hybrid SWOT-SHP analysis of ICT enabled control systemin the process industry-A case study. International Journal of Computer Applications 72(4):9-14.

20. Juwono R, Sumanang NMA. 2016. Analisa potensi Kota Batam sebagai pusat pengembangan industri Teknologi Informasi dan Komunikasi. IT for Society 1(2):36-41.

21. Juwita O, Hartadi AD. 2016. Analisa SWOT untuk strategi pengembangan teknologi informasi pada koperasi simpan pinjam XYZ. Informatics Journal 1(1):1013.

22. Kangas J, Pesonen M, Kurtilla M, Kajanus M. 2001. A'WOT: integrating the AHP with SWOT analysis. Proceedings 6thISAHP. 189-198

23. Klein HK, Myers MD. 1999. A Set of Principles for Conducting and Evaluating Interpretative Field Studies in Information Systems. MIS Quarterly. 23(1):67-88.

24. Kouzes JM, Posner BZ. 1987. The Leadership Challenge: How to Get Extraordinary Things Done in Organizations. San Francisco:Jossey-Bass.

25. KPMG. 2018. The Cloud - Changing the Business Ecosystem. KPMG International Cooperative.

26. Kurniawati L. 2017. Analisis perencanaan strategi teknologi dan sistem informasi perusahaan. Information System for Educators and Professionals. 1(2):125-138.
27. Magdalena H. 2013. Strategi memilih perangkat lunak pembagi bandwidth tanpa mikrotik untuk warnet. Seminar Nasional Teknologi Informasi dan Komunikasi.; Yogyakarta, Indonesia. Yogyakarta: hlm 189-196; [Diunduh 2021 Maret 06]. https://fti.uajy.ac.id/sentika/publikasi/makal ah/2013/2013_28.pdf

28. Mihajlovic I. 2012. The Impact of Information and Communication Technology (ICT) as a Key Factor of Tourism Development on the Role of Croatian Travel Agencies. International Journal of Business and Social Science. 3(24):151-159.

29. Mildawati T. 2000. Teknologi Informasi dan Perkembangannya di Indonesia. Ekuitas. 4(2) : 101-110.

30. Mintzberg H. 1975. The manager's job: Folklore and fact. Harvard Business Review:49-61.

31. Moshiri S, Simpson W. 2011. Information Technology and the Changing Workplace in Canada: Firm-level Evidence. Industrial and Corporate Change. 20(6):1601-1636. doi:10.1093/icc/dtr029

32. Nurhayati S. 2009. Analisis strategis sistem teknologi informasi dengan pendekatan analisis SWOT (Studi Kasus: Divisi IT Rumah Sakit Mata Cicendo Bandung). Seminar Nasional Informatika. Yogyakarta: hlm 149-154; [Diunduh 2020 Desember 17]. http://jurnal.upnyk.ac.id/index.php/semnasif /article/view/917

33. Rahman A, Dewantara RY. 2017. Pengaruh Kemudahan Penggunaan dan Kemanfaatan Teknologi Informasi terhadap Minat Menggunakan Situs Jual Beli Online. Jurnal Administrasi Bisnis. 52(1):1-7.

34. Rangkuti F. 2016. Analisis SWOT: Teknik Membedah Kasus Bisnis. Es ke 22, Cetakan ke 22. Jakarta (ID): Gramedia Pustaka Utama.

35. Raymond MLB, Ine M, Iwang G. 2012. Analisis pengembangan usaha pemindangan ikan di Kecamatan bekasi Barat. Jurnal Perikanan dan Kelautan. 3(1): 17-24.

36. Riyanto S. 2018. Analisis pengaruh lingkungan internal dan eksternal terhadap keunggulan bersaing dan kinerja Usaha Kecil Menengah (UKM) di Madiun. Jurnal Manajemen Bisnis dan Inovasi. 5(3):159168.

37. Roosdhani MR, Wibowo PA, Widiastuti A. 2012. Analisis tingkat penggunaan 
teknologi informasi dan komunikasi pada usaha kecil menengah di Kab. Jepara. Jurnal Dinamika Ekonomi dan Bisnis. 9(2):89-104.

38. Rouse WB. 1998. Don't Jump to Solutions: Thirteen Delusions that Undermine Strategic Thinking. San Francisco: JosseyBass.

39. Rouse WB. 2005. A theory of enterprise transformation. Systems Engineering 8(4):279-295.

40. Rouse WB. 2006. Ed. Enterprise Transformation: Understanding and Enabling Fundamental Change. New York: Wiley.

41. Selwyn N. 2007. The Use of Computer Technology in University Teaching and Learning. Journal of Computer Assisted Learning. 23(1): 83-94

42. Simon HA. 1957. Models of Man: Social and Rational. New York:Wiley.

43. Simon HA. 1969. The Sciences of the Artificial. Cambridge:MIT Press.

44. Solihin I. 2012. Manajemen Strategik. Jakarta (ID): Penerbit Erlangga.

45. Vrana R. 2010. ICT-supported Communication of Scientist and Teaching Staff at the Faculty of Humanities and Social Sciences in Zagreb. New Library
World. 111(9/10): 413-425. DOI $10.1108 / 03074801011089332$.

46. Wang, K. Y. (2006). Information Behaviors in the Digital Environment: A Case Study of Humanities and Social Sciences Scholars. [Tesis]. Canada (CAN) : University of Alberta.

47. Yuliana R. 2013. Analisis strategi pemasaran pada produk sepeda motor matik berupa segmentasi, targeting, dan positioning serta pengaruhnya terhadap keputusan pembelian konsumen di Semarang. Jurnal STIE Semarang. 5(2):7992.

48. Zhang X. 2010. Facilitating Knowledge Management System Success: Roles of Technologies, Management and Social Networks. [Tesis]. Arkansas (USA) : University of Arkansas

How to cite this article: Adityo Suryo Dwiatmono, Arief Daryanto, Raden Dikky Indrawan. ICT industry business development strategy in Indonesia (case study: PT. XYZ). International Journal of Research and Review. 2022; 9(2): 436-451. DOI: https://doi.org/ 10.52403/ijrr.20220256 